The Turkish Online Journal of Design, Art and Communication - TOJDAC

ISSN: 2146-5193, March 2018 Special Edition, p. 419-427

\title{
PRODUCTIVE QUALITIES OF CATTLE DEPENDING ON THE BREED
}

\author{
Sukhanova S.F. ${ }^{1}$, Alekseeva E.I. ${ }^{2}$, Lushnikov N.A. ${ }^{3}$, Leshchuk T.L. ${ }^{4}$, Koshelev S.N. ${ }^{5}$, Uskov G.E. ${ }^{6}$, \\ Pozdnyakova N.A.7, Dostovalova L.G. ${ }^{8}$
}

${ }^{1}$ Doctor of Agricultural Sciences (Advanced Doctor), Academician, Pro-rector on Research,

2Master of Arts (M.A.), Assisstant Professor,

Associate Professor at Chemistry and Food Commodities Inspection Department,

3Doctor of Agricultural Sciences (Advanced Doctor), Academician,

Head of Biology and Veterinary Department,

${ }^{4}$ Doctor of Agricultural Sciences (Advanced Doctor), Associate Professor,

Academician at Private Zootechnics, Feeding and Breeding of Farm Animals Department,

${ }^{5}$ Doctor of Biological Sciences (Advanced Doctor), Academician,

Head of Private Zootechnics, Feeding and Breeding of Farm Animals Department,

${ }^{6}$ Doctor of Agricultural Sciences (Advanced Doctor), Associate Professor,

Academician of Private Zootechnics, Feeding and Breeding of Farm Animals Department,

${ }^{7}$ Master of Arts (M.A.), Assisstant Professor, Associate Professor at Biology and Veterinary Department,

8Postgraduate

\begin{abstract}
The breed is a factor that determines the productivity of cattle. In the domestic and foreign literature there are numerous data on the economic characteristics of meat breed cattle but there is little reliable information about the productive features of a particular breed in the conditions of a certain region. In this regard the study of the productivity of beef cattle of different breeds in the conditions of the Kurgan region is an actual problem. The studies were conducted in the farms of Kurgan region in 2013-2014 on the young Aberdeen-Angus and Hereford breeds. It was established that the main reserve of beef production in Kurgan region is the intensive growing and fattening of the young Aberdeen-Angus and Hereford breeds (31.53 and 63.51\% respectively, of the total number of livestock). The animals of the Aberdeen-Angus breed showed better productivity and economic efficiency in comparison with the Hereford animals: a body weight of 524.55 and $476.80 \mathrm{~kg}$ in 18 months, a slaughter yield of 61.2 and $60.8 \%$, a protein conversion ratio of 16.31 and $16.15 \%$, the level of profitability of 20.98 and $13.91 \%$ respectively. During the entire period of cultivation (0-18 months) the animals of the Aberdeen-Angus breed consumed a smaller amount of EFU (energetic feed unit), exchange energy and digestible protein per $1 \mathrm{~kg}$ of body weight growth - $6.23 \mathrm{EFU}, 62.25 \mathrm{MJ}$ and 540 g. The breed factor influences a significant effect on the average daily weight gain $(12.82 \%)$, dry matter content in the pulp (42.27\%), fat content in the pulp (73.72\%), energy value of the pulp (58.95\%), conversion rate of the energy exchange (59.14\%). To increase the production of beef in Kurgan region it is recommended to breed the animals of the Aberdeen-Angus breed.

Keywords: breed, cattle, Aberdeen-Angus breed, Hereford breed, growth, development, meat productivity, protein conversion, metabolic energy conversion factors, force of factor influence, coefficients of correlation, elasticity, determination.

\section{INTRODUCTION}

The development of effective measures for the development of cattle breeding in Russia takes place in the new social, organizational and economic conditions of the industry [9]. It is necessary from the standpoint of modern science and practice to assess in detail and realistically the initial state in the selection and breeding work organization $[1 ; 3 ; 14 ; 27 ; 28]$. It is the breed that is the main
\end{abstract}

Submit Date: 09.01.2018, Acceptance Date: 23.02.2018, DOI NO: 10.7456/1080MSE/149

Research Article - This article was checked by Turnitin

Copyright (C) The Turkish Online Journal of Design, Art and Communication 
means of milk and beef production [2] and is a factor that determines the productivity of cattle. Meat cattle breeding in Russia has undergone significant changes for two decades. So, 3989 thousand tons of beef in 1991, in 2001 - 1879 thousand tons, in 2010 - 1727 thousand tons, and in $2016-1623$ thousand tons were produced in slaughter weight (collectively from cattle of dairy and meat breeds). Recently there have been positive trends in Russia in providing the country's population with meat of national production and meat products in general, but beef is a stable negative trend - the level of selfsufficiency in beef decreased from 51.7 to $45.6 \%$. The stimulus for the development of the meat cattle breeding industry was the adoption of the sectoral target program "Development of meat cattle breeding in Russia in 2009-2012" in 2009 [8; 15; 29]. The producers began to be engaged in cultivation of specialized meat cattle in Kurgan region since 2007. During this period in the APC "Krutikhinsky" from Chelyabinsk region 159 head of Hereford purebred breeding heifers were delivered. In 2008 LLC "Suer" bought in Australia 412 Aberdeen-Angus breed heifers. In 2010759 heifers of Hereford breed were brought to CJSC "Polesye", LLC "Arman" bought 337 heads of Kazakh white-headed cattle in the Republic of Kazakhstan. In 201160 heifers Hereford breed were imported in PF "Shatalin K.V.". In December 2011 PF "Pshenichnikova T.K." purchased 45 breeding heifers of Aberdeen-Angus breed [17; 24]. This breeding stock became the basis for the cultivation of specialized beef cattle in the Urals. The impetus for the development of beef cattle in Kurgan region was the departmental target program of the Department of Agriculture and Processing Industry in Kurgan region "Development of beef cattle for 2011-2015" [10; 12]. The implementation of the Program allowed increasing the number of beef cattle from 2089 heads to 6531 during this period, including cows from 666 to 2898 heads [11]. As of April 1, 2018 the number of beef cattle in Kurgan region amounted to 16.550 heads, including 7377 cows. The breeding of cattle of meat direction productivity is engaged in 73 farms, including 16 agricultural organizations and $57 \mathrm{PF}$. The structure of the breed composition of cattle meat productivity direction is as follows: Hereford cattle $-63.51 \%$, Aberdeen-Angus - 31.53\%, Kalmyk - 0.65\%, Kazakh white-headed - 0.98\%, Auliekolsky $-2.72 \%$, Charolais $-0.33 \%$, Obrak $-0.28 \%$. In national and foreign literature there are numerous data on economic and useful signs of cattle of meat breeds, but little reliable information on productive features of concrete breed in the conditions of a certain region. In this regard, the study of the productivity of beef cattle of different breeds in Kurgan region is an urgent problem.

\section{MATERIALS AND METHODS}

The research was carried out in the farms of Kurgan region in 2014-2015 on young AberdeenAngus and Hereford breeds. To study the dynamics of growth and development, two groups of animals were formed, 30 animals in each: I - bulls of Aberdeen-Angus breed, II - bulls of Hereford breed. The experimental animals were selected by the method of balanced groups-analogs in age and live weight [16]. Changes in live weight were studied from birth to 18 months of age (inclusive). Absolute, relative and daily average gains of animals were calculated by the method of A. Mayanot in modification by S. Brody (1927). Productivity was determined by control slaughter of 3 bulls from each group at the age of 18 months according to the methods of FSCAH and FRCS $(1972 ; 1977)$. In the study of meat qualities of the studied animals the following indicators were taken into account: live weight, slaughter weight, slaughter yield, chemical composition of meat. Study of conversion of protein and metabolizable energy of feed products was performed by the method of L.K. Lepaye $(1975,1983)$. The efficiency of beef production from meat breeds was determined by the method of UAAS (1983), taking into account the current prices. Biometric processing of the obtained experimental data was performed using the programs "Excel"and "FACTOR_ANALYSER", the Single-factor dispersive analysis service $[18 ; 19 ; 20 ; 21 ; 22 ; 23]$.

\section{RESULTS}

The studies found that at birth large live weight was in Hereford bulls $-29.31 \mathrm{~kg}$, the difference with peers of the Aberdeen-Angus breed is made up $3.03 \mathrm{~kg}$. In subsequent months animals of the Aberdeen-Angus breed had authentic superiority on live weight. Thus, during the weaning period, the indicator was higher by $46.28 \mathrm{~kg}(20.45 \%)$, at 18 months - by $47.75 \mathrm{~kg}(9.10 \%)(\mathrm{D}<0.001)$ (Figure 1, a).

Fluctuations of daily increase of live weight of meat cattle were revealed: Hereford from 570 to $1055 \mathrm{~g}$, Aberdeen anguss - from 837 to $1061 \mathrm{~g}$. The average daily growth of Aberdeen anguss was higher than Hereford in the first month of life by $263 \mathrm{~g}(25.02 \%)(\mathrm{R}<0.001)$, in the second and third - 
by $309(30.96 \%)(\mathrm{d}<0.001)$ and $225 \mathrm{~g}(22.84 \%)(\mathrm{D}<0.001)$, the fourth, fifth, sixth, seventh, eighth, fifteenth and seventeenth - by $137(13.37 \%)(\mathrm{D}<0.05), 387 \quad(40.44 \%) \quad(\mathrm{D}<0.001), 75 \quad(8.06 \%)$ $(\mathrm{D}<0.05), 248$ (27.29\%) $(\mathrm{D}<0.001), 94(10.27 \%)(\mathrm{D}<0.05), 33$ (3.11\%) and $42(4.58 \%) \mathrm{g}$. Bulls of Hereford breed had an advantage on average daily growth over bulls of Aberdeen-Angus breed in nine, eleven, twelve, thirteen and eighteen months of life by $31(3.15 \%), 108(10.24 \%)(\mathrm{D}<0.05), 2$ $(0.21 \%), 8(0.84 \%), 72(7.12 \%)(\mathrm{D}<0.05)$ and $35(3.79 \%)$ g, respectively (Figure $1, b)$.

The absolute increase in live weight from birth to weaning was: the bulls of Hereford breed $152.07 \mathrm{~kg}$, and Aberdeen-Angus - $200.00 \mathrm{~kg}$, i.e. the difference in the indicator was $47.93 \mathrm{~kg}$ $(23.97 \%)(\mathrm{D}<0.001)$ in favor of the second one. The absolute increase in live weight of animals from birth to 18 months was greater in bulls of Aberdeen-Angus breed than Hereford breed by $43.41 \mathrm{~kg}$ $(8.57 \%)(\mathrm{D}<0.001)$ (Figure 1, c). The growth rate was also higher in young cattle of Aberdeen-Angus breed: in the period from birth to weaning the difference was $28.69 \%(\mathrm{D}<0.001)$, from birth to 18 months $-18.49 \%(\mathrm{D}<0.05)$ (Figure 1, d).

Among the bulls of the considered breed, the Aberdeen Angus grew more intensively by $25.2 \%$ $(\mathrm{D}<0.001)$ than the Herefords (Figure 1, e). The uniformity of growth was slightly better, on the contrary, in the Herefords, the difference $-1.1 \%$. The growth intensity of the Aberdeen-Angus breed bulls was lower by $8.6 \%(\mathrm{D}<0.001)$.

The results of the control slaughter and indicators of animals' meat productivity are shown in Figure 2. Live weight of the Aberdeen-Angus breed bulls was $537 \mathrm{~kg}$, which is more than standard for the breed by $77 \mathrm{~kg}$. After hungry aging before slaughter live weight decreased by $17.30 \mathrm{~kg}$. Carcass weight was $318 \mathrm{~kg}$, including the mass of the pulp $-357.70 \mathrm{~kg}$, bones $-52.43 \mathrm{~kg}$. Live weight of Hereford breed bulls was $511 \mathrm{~kg}$. After hungry aging before slaughter live weight decreased by $6.3 \mathrm{~kg}$. Carcass weight amounted to $307 \mathrm{~kg}$, including the mass of the pulp $-249.2 \mathrm{~kg}$, bones $-48.9 \mathrm{~kg}$. On live and pre-slaughter weight the bulls of the Aberdeen-Angus breed exceeded the bulls of the Hereford breed by 26 and $15 \mathrm{~kg}$ (4.84 and 2.89\%), respectively. Carcass weight and pulp weight were also higher in Aberdeen-Angus bulls than in Hereford bulls, by 11.0 and $8.2 \mathrm{~kg}$ (3.46 and $3.18 \%$ ), respectively. The number of bones in the carcass of bulls of Hereford breed was $3.4 \mathrm{~kg}(6.49 \%)$ $(\mathrm{D}<0.01)$.

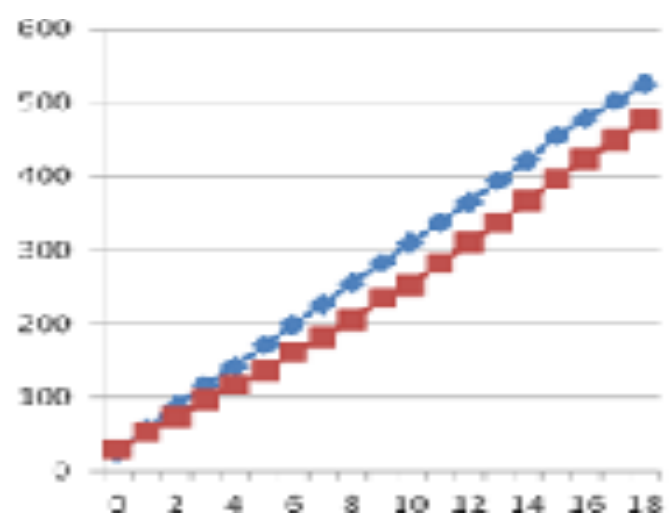

a)

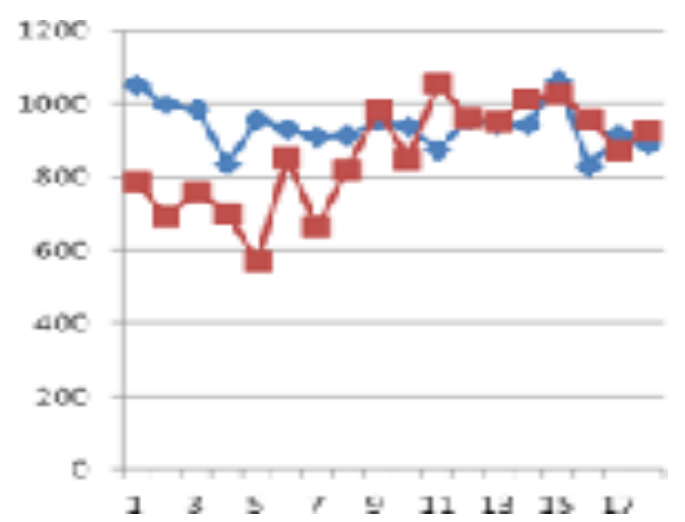

b) 


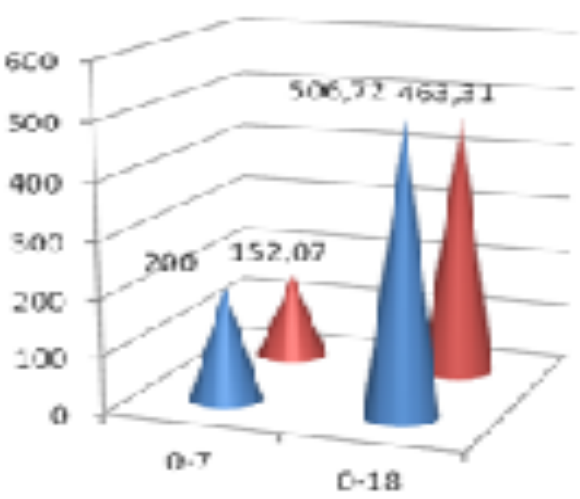

c)

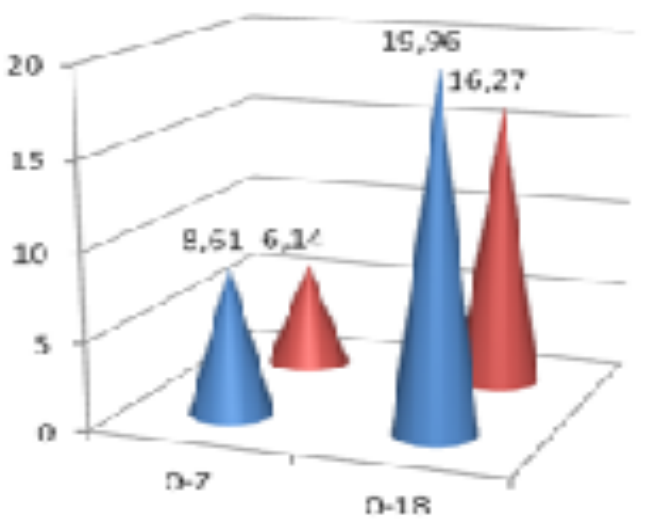

d)

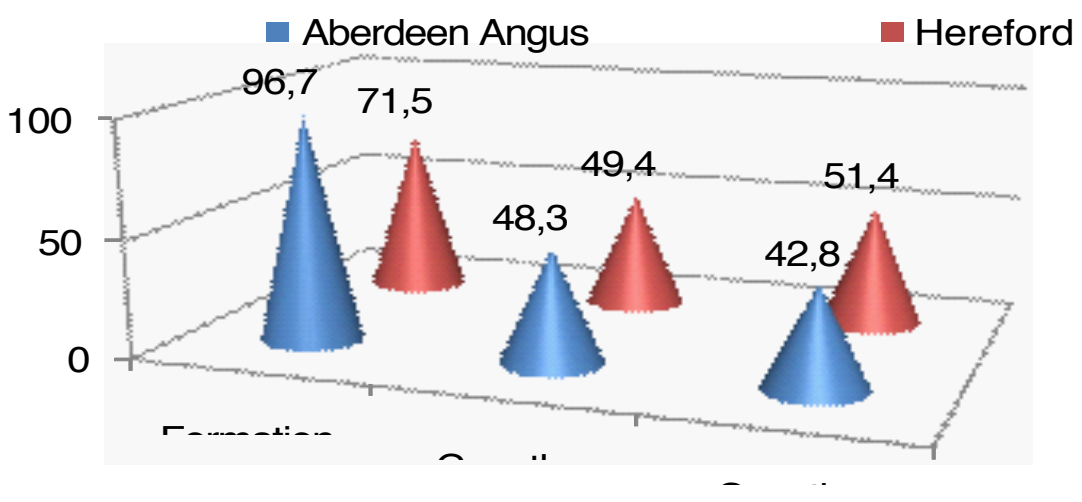

e)

Figure 1 - Growth and development of young cattle of Aberdeen-Angus and Hereford breeds: a) live weight, $\mathrm{kg}$; b) average daily live weight gain, $\mathrm{g}$; c) absolute increase in live weight, kg; d) growth rate; e) bull development indicators, \%

Slaughter yield of animals of Aberdeen-Angus and Hereford breeds was 61.2 and $60.8 \%$ respectively, the difference was $0.4 \%$. Increased value of the carcass inedible parts yield (content of bones, cartilage, and trim) slightly reduced the meat content coefficient. Thus, the Aberdeen Angus indicator was 4.27 , Hereford -4.33 , the difference of $1.39 \%$ in favor of the second breed. The flesh content per $1 \mathrm{~kg}$ of live weight was high and almost the same - $496.0 \mathrm{~g}$ in Aberdeen-Angus breed bulls and $493.7 \mathrm{~g}$ - Hereford, the difference of $0.46 \%$. The net growth of young cattle of AberdeenAngus and Hereford breeds was 589 and $568 \mathrm{~g}$, the difference between the breeds was $21 \mathrm{~g}(3.57 \%)$. 


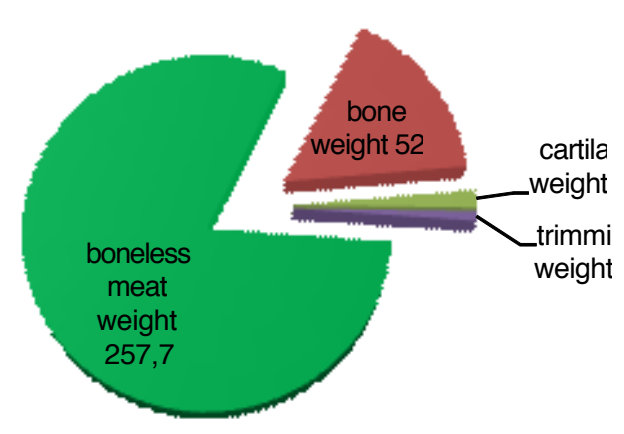

a

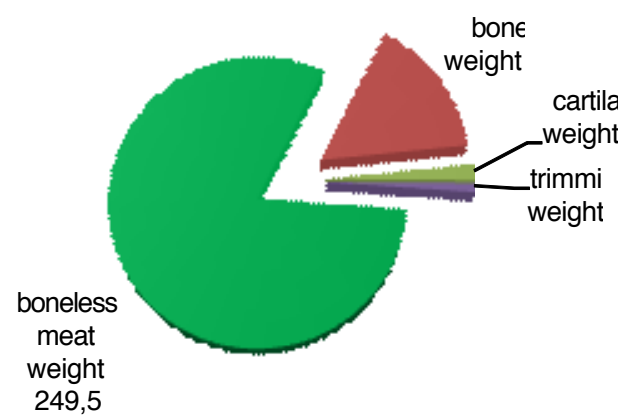

b

Figure 2 - Results of the control slaughter of Aberdeen-Angus (a) and Hereford (b) breed bulls, kg

For the entire animals' growing period (0-18 months) fewer number of EFU, metabolizable energy and digestible protein per $1 \mathrm{~kg}$ of live weight gain was spent by the Aberdeen-Angus breed bulls $-6.23 \mathrm{EFU}, 62.25 \mathrm{MJ}$ and $540 \mathrm{~g}$. The difference with the Hereford breed was $0.63 \mathrm{EFU}(9.18$ $\%), 5.99 \mathrm{MJ}(8.78 \%)$ and $52 \mathrm{~g}(8.78 \%)$ respectively.

Studies of the chemical composition of beef showed that in the meat of young cattle of Hereford breed mass fraction of moisture was $68.67 \%$, dry matter $-31.33 \%$, including protein $19.07 \%$, fat $-11.30 \%$, minerals $-0.97 \%$. In the meat of Aberdeen Angus the moisture content was $73.13 \%$, dry matter $-26.87 \%$, including protein $-18.63 \%$, fat $-7.43 \%$, minerals $-0.80 \%$. A comparative analysis of the chemical composition of meat of the species under consideration showed that lower moisture content and higher dry matter content were observed in Herefords, the difference was $4.46 \%$. In the meat of Hereford breed bulls the content of protein and minerals was higher than in the meat of Aberdeen-Angus breed ones, by $0.44 \%$ and $0.17 \%$ respectively. Lower fat content was observed in the meat of Aberdeen-Angus breed bulls, the difference was $3.87 \%$. To calculate the conversion factors of protein and the exchange energy of the diet into meat products, the amount of protein consumed and exchange energy for the entire period of bull-rearing was determined. Thus, the amount of protein was $294.33 \mathrm{~kg}$, and the exchange energy - 34332.6 MJ. The higher protein content and lower fat content was in the flesh of Aberdeen-Angus breed bulls 48.00 and $19.14 \mathrm{~kg}$, the difference with Hereford was $3.43(7.16 \%)$ and $8.17(42.11 \%)(\mathrm{D} \leq 0.01) \mathrm{kg}$, respectively.

The conversion rates of protein and exchange energy in the group of the Aberdeen-Angus breed bulls were 16.31 and $4.56 \%$, and in the Hereford breed bulls -16.15 and $5.57 \%$, i.e. the protein conversion rate was higher by $0.16 \%$ in the group of Aberdeen-Angus, and the conversion rate by $1.01 \%$ in the Hereford.

The cost of 1 centner growth of live weight of Aberdeen-Angus and Hereford cattle was 11985.00 and 13542.00 rubles, respectively, i.e. the difference of 1944.00 rubles. The more profit was received from the sale of Aberdeen-Angus in 8234.09 rubles. The level of profitability of beef production from Aberdeen-Angus cattle was $20.98 \%$, from Hereford - $7.07 \%$, the difference $13.91 \%$.

Single-factor dispersive analysis established the power of the factor "breed" influence on the performance and quality of meat (Figure 3). Thus, a significant degree of influence of the factor $(\mathrm{D} \leq 0.01)$ was revealed on the average daily increase in live weight $(12.82 \%)$, the dry matter content in the pulp $(42.27 \%)$, the fat content in the pulp $(73.72 \%)$, the energy value of the pulp $(58.95 \%)$, the conversion rate of exchange energy (59.14\%). Reliable influence of the factor is not defined on other indicators.

To obtain more complete description of the animals productivity of the species under consideration, a regression analysis of the indicators "average daily increase in live weight - the intensity of formation", "live weight during weaning - pre-slaughter weight", "absolute increase in live weight before weaning -carcass weight" was performed. The correlation coefficients (Figure 4, a), elasticity (Figure 4, b), determination (Figure 4, c) were taken into account. 


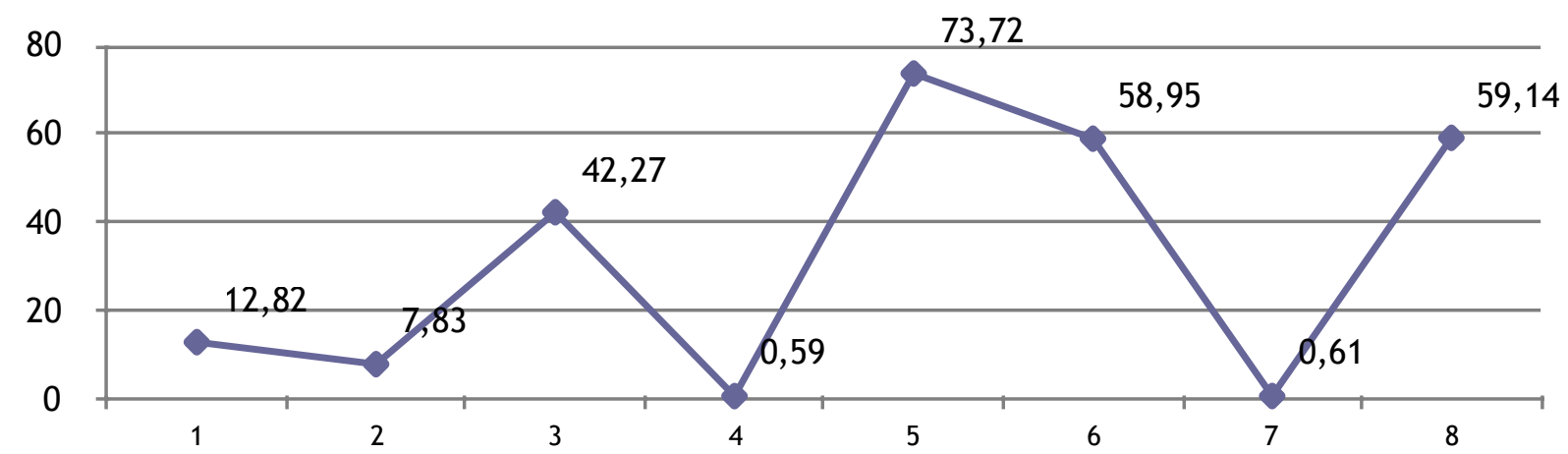

Figure 3 - Power of influence of the "breed" factor on the indicators of productivity and quality of meat, \%: 1 - average daily live weight gain; 2 - the pulp mass; 3 - dry matter content in the pulp; 4 - the protein content in the pulp; 5 - the fat content of the pulp; 6 - the energy value of the pulp; 7 - the conversion rate of protein; 8 - the conversion rate of exchange energy

It was established that the Aberdeen-Angus breed bulls have a high and direct relationship between the indicators of "average daily live weight gain - the intensity of formation" ( $r=0.76)$. At the same time, the coefficient of elasticity shows a significant dependence of these indicators, that is, with an increase in the value of one by $1 \%$, the second increases by $1.83 \%$, and the coefficient of determination indicates that the intensity of formation is determined by the average daily increase of 57.94\%. In the group of Hereford breed bulls the relationship between these indicators is moderate and direct $(\mathrm{r}=0.44)$, with an increase in the average daily growth of $1 \%$, the intensity of formation increased by $1.12 \%$, in $19.1 \%$ of cases, the change in the average daily growth leads to a change in the rate of formation. The coefficients are statistically significant and the regression equation is statistically reliable, the results are reliable with a probability of $95 \%$.

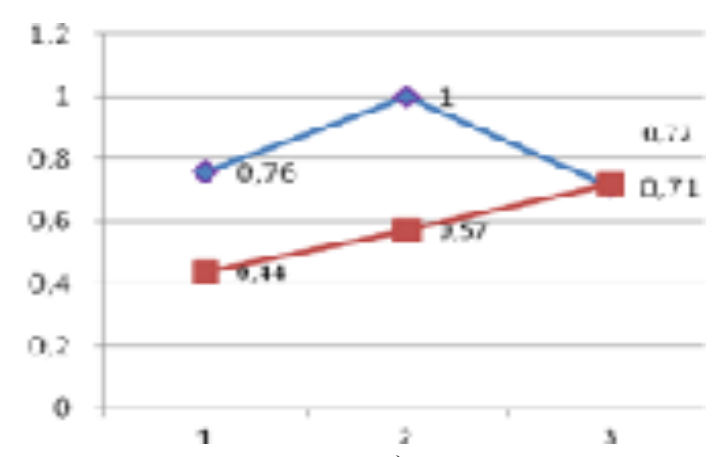

a)

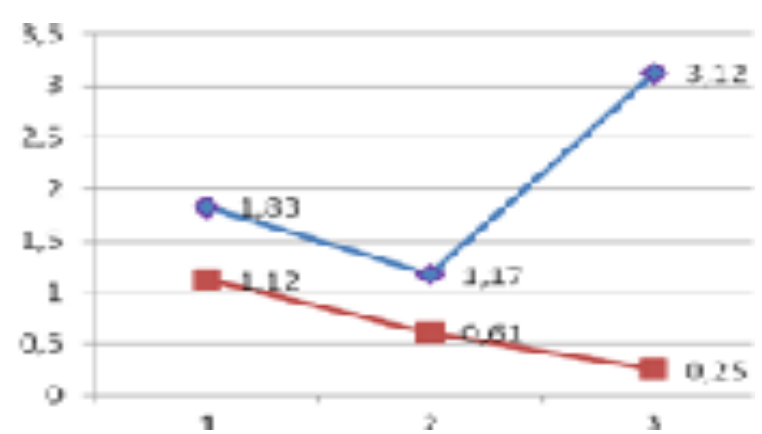

b)

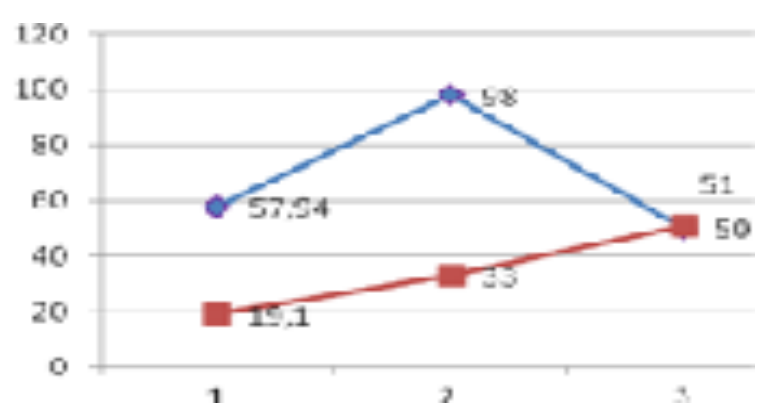

c)

Figure 4 - Correlation and dependence of productivity indicators ( 1 - average daily live weight gain - the intensity of the formation; 2 - live weight at weaning - pre-slaughter weight; 3 - the absolute live weight gain before weaning - carcass weight):

a) correlation coefficient; b) elasticity coefficient; c) coefficient of determination. 
In the Aberdeen-Angus breed bulls a connection between the "live weight at weaning - preslaughter weight" indicators according to the scale of Chaddock is very high and positive $(\mathrm{r}=0,92)$, the increase in live weight at weaning by $1 \%$ will lead to an increase in slaughter weight by $1.17 \%$. The pre-slaughter weight depends on the live weight at weaning at $98.0 \%$ and by $2.0 \%$ is determined by unaccounted factors. In young cattle of Hereford breed the relationship between the indicators is noticeable and direct $(\mathrm{r}=0.57)$, the increase in live weight at weaning by $1 \%$ will lead to an increase in pre-slaughter weight by $0.61 \%$. Pre-slaughter weight depends on live weight at weaning at $33,0 \%$ and by $67,0 \%$ is determined by unaccounted factors.

The relationship between the indicators "absolute live weight gain before weaning - carcass weight" in Aberdeen-Angus breed bulls is very high and direct $(\mathrm{r}=0.71)$, an increase in the absolute live weight gain before weaning by $1 \%$ will increase the carcass weight by $3.12 \%$, carcass weight depends on the absolute live weight gain before weaning by $50.0 \%$ and by $50.0 \%$ is determined by unaccounted factors. The relationship between the considered features of Hereford breed bulls is high and direct $(\mathrm{r}=0.72)$. The magnitude of the coefficient of elasticity can show that the increase in absolute live weight gain before weaning by $1 \%$, carcass weight will increase by $0.25 \%$, carcass weight depends on the absolute live weight gain before weaning by $51.0 \%$ and $49.0 \%$ is determined by unaccounted factors.

\section{CONSIDERATION}

Currently the process of evaluation and improvement of beef cattle in Russia has received a special development due to a major revision of the attitude to the problem of food security [5]. This is fixed by the adoption of the "Doctrine of food security of the Russian Federation" (app. by Decree of the President of the Russian Federation of January 30, 2010 №120), according to which it is expected to reduce the share of imported beef in the Russian market less than 15\% [13]. Understanding the dependence of our country on food imports became the basis for the Government of the Russian Federation to prepare and implement a number of sectoral programs aimed at the development of the national meat cattle breeding industry. The first such program became the sectorial one "Development of meat cattle breeding in Russia in 2009-2012". The further stage of the industry development was the adoption of the Subprogram "Meat cattle breeding" within the state program "Development of agriculture and regulation of markets of agricultural products, raw materials and food for 2013-2020" with the total funding of 62.04 billion rubles. At the same time, along with a set of financial solutions the industry can not get out of the crisis without technological re-equipment, which becomes possible with the emergence of new productive forces, which in the livestock industry are beef cattle breeds [4]. Therefore, the study of the productive characteristics of beef cattle is an important and urgent task.

The cattle of meat productivity direction are characterized by high intensity of growth and reach a large live mass at an early age [25; 26]. Studies established that the Aberdeen-Angus breed bulls exceeded in terms of productivity the young cattle of Hereford breed. So, at the birth large live mass was in Hereford bulls - $29.31 \mathrm{~kg}$, the difference with peers of the Aberdeen-Angus breed is made up of $3.03 \mathrm{~kg}$. In subsequent months authentic superiority on live weight was in Aberdeen Angus animals $(\mathrm{D}<0.001)$. Thus, in the period of weaning the indicator was higher by $46.28 \mathrm{~kg}$, in the 18 month age by $47.75 \mathrm{~kg}$. Also in Herefords a high value of the index of growth tension $-51.4 \%$, which is undesirable was revealed. The Aberdeen-Angus breed bulls had a pre-slaughter weight, carcass and pulp weight by $4.56,3.46$ and $3.18 \%$, higher protein content and less fat - by 7.15 and $29.92 \%$, respectively, the protein conversion rate - by $0.16 \%$.

The revealed features of productivity are characteristic for the Aberdeen-Angus breed animals and were previously stated in the studies of Shchukina I.V. (2013), Sheveleva O.M. (2017) [29; 30]. In principle this circumstance plays an important role for the breed competitiveness.

At developing measures to increase the productivity of cattle it is necessary to know the nature of the relationship and the interrelation between the various characteristics [6; 7]. Thus, in our studies using a single-factor dispersive analysis a significant force of influence of the factor "breed" on the average daily live weight gain $(12.82 \%)$, the dry matter content in the pulp (42.27\%), fat content in the pulp $(73.72 \%)$, the energy value of the pulp (58.95\%), conversion rate of exchange energy $(59.14 \%)$ was established. The method of regression analysis revealed that between the indicators of "average daily live weight gain - the intensity of formation", "live weight during weaning - pre-slaughter weight", "absolute live weight gain before weaning - carcass weight" there is a direct relationship $(\mathrm{r}=0.44-1.00)$, the dependence $(\beta=1.12-3.12)$ and the impact of indicators on each other 
$(\mathrm{R}=19.1-98.0 \%)$. The obtained results are confirmed by studies of Plutakhin G.A., Koshchaev A.G., Donnik I.M. (2016).

The generalization of the obtained experimental material allowed us to formulate conclusions.

1. The main reserve of beef production in Kurgan region is intensive cultivation and fattening of young cattle of Aberdeen-Angus and Hereford breeds (31.53 and 63.51\%, respectively, of the total livestock).

2. Animals of the Aberdeen-Angus breed showed better productivity and economic efficiency in comparison with animals of Hereford breed: the difference in live weight in 18 months was $9.10 \%$, slaughter yield $-0.40 \%$, protein conversion rate $-0.16 \%$, the level of profitability $-7.07 \%$.

3. During the whole period of growing (0-18 months) animals of the Aberdeen-Angus breed in comparison with young cattle of Hereford breed spent less number of EFU, exchange energy and digestible protein per $1 \mathrm{~kg}$ of live weight gain by $9.18,8.78$ and $8.78 \%$, respectively.

4. The "breed" factor had a significant impact on the average daily live weight gain $(12.82 \%)$, the dry matter content in the pulp (42.27\%), the fat content in the pulp (73.72\%), the energy value of the pulp (58.95\%), the conversion rate of exchange energy (59.14\%).

5. Between the indicators of "average daily live weight gain - the intensity of formation" in the Aberdeen-Angus and Hereford breed bulls the connection is high and direct, moderate and direct, with an increase in the value of one by $1 \%$, the second increases by 1.83 and $1.12 \%$, the intensity of formation is determined by the average daily increase of 57.94 and $19.1 \%$, respectively. The relationship between the indicators of "live weight at weaning - pre-slaughter weight" is very high and direct, noticeable and direct, increasing live weight at weaning by $1 \%$ will increase the preslaughter weight by 1.17 and $0.61 \%$, pre-slaughter weight depends on the live weight at weaning by 98.0 and $33.0 \%$, respectively. The connection between the indicators of "absolute live weight gain before weaning - carcass weight" is very high and direct, an increase in the absolute live weight gain before weaning by $1 \%$ will contribute to an increase in carcass weight by 3.12 and $0.25 \%$, carcass weight depends on the absolute live weight gain before weaning by 50.0 and $51.0 \%$, respectively.

6. To increase beef production in Kurgan region is recommended to breed animals of AberdeenAngus breed.

\section{REFERENCES}

Chasovshchikova M.A., Sheveleva O.M., Svjazhenina M.A., Tatarkina N.I., Satkeeva A.B., Bakharev A.A., Ponomareva E.A., Koshchaev A.G. RELATIONSHIP BETWEEN THE GENETIC VARIANTS OF KAPPA-CASEIN AND PROLACTIN AND THE PRODUCTIVE-BIOLOGICAL CHARACTERISTICS OF COWS OF THE BLACK-MOTLEY BREED // Journal of Pharmaceutical Sciences and Research. 2017. T. 9. № 7. C. 1038-1044.

Donnik I.M., Krivonogova A.S., Isaeva A.G., Koshchaev A.G., Neverova O.P., Bykova O.A. PRODUCTIVITY AND HEALTH MARKERS FOR LARGE CATTLE // International Journal of Green Pharmacy. 2017. T. 11. № S3. C. S620-S625.

Koshchaev A.G., Shchukina I.V., Semenenko M.P., AnnaSergeevna K., Vasilevich K.V. AMINO ACID PROFILE OF MEAT OF SPECIALIZED BEEF BREEDS // Research Journal of Pharmaceutical, Biological and Chemical Sciences. 2016. T. 7. № 5. C. 670-676.

Osadchuk L.V., Kleshchev M.A., Sebezhko O.I., Korotkevich O.S., Shishin N.I., Konovalova T.V., Narozhnykh K.N., Petukhov V.L. CHARACTERIZING PHYSIOLOGICAL STATUS IN THREE BREEDS OF BULLS REARED UNDER ECOLOGICAL AND CLIMATE CONDITIONS OF THE ALTAI REGION // Iraqi Journal of Veterinary Sciences. 2017. T. 31. № 1. C. 35-42.

Patieva S.V., Patieva A.M., Lisovitskaya E.P., Zabashta N.N. THE QUALITY AND SAFETY OF MEAT RAW MATERIALS FOR THE PRODUCTION OF HEALTHY FOOD // Research Journal of Pharmaceutical, Biological and Chemical Sciences. 2016. T. 7. № 2. C. 731-737.

Plutakhin G.A., Koshchaev A.G., Donnik I.M. QUALITY ASSESSMENT OF CHICKEN MEAT BY ANALYSIS-OF-VARIANCE METHOD // Research Journal of Pharmaceutical, Biological and Chemical Sciences. 2016. T. 7. № 3. C. 2293-2299.

Azaubaeva G.S., Sukhanova S.F., Leshchuk T.L. Creation of the program "FACTOR_ANALYSER" for determining the influence degree of various factors on biological systems // In the collection: Modern methods of teaching and research work Materials of the All-Russian Scientific and Practical Conference. 2017. pp. 7-11

Alekseeva E.I. Meat production of Aberdeen-Angus and Hereford breed in Zauralye // Chief herd manager. - 2017. - № 3. - P.42-47.

Submit Date: 09.01.2018, Acceptance Date: 23.02.2018, DOI NO: 10.7456/1080MSE/149

Research Article - This article was checked by Turnitin

Copyright (C) The Turkish Online Journal of Design, Art and Communication 
Alekseeva E.I., Leshchuk TL, Leshchuk G.P. Research of some questions of the conjuncture of the beef market // Feeding of agricultural animals and fodder production. 2014. № 4. P. 66-72.

Alekseeva E.I., Lushnikov N.A., Leshchuk T.L. Results of the meat quality evaluation of the AberdeenAngus breed bulls // Vestnic of Kurgan State Agricultural Academy. - 2014. - №3. - P.53-57.

Alekseeva E.I., Sukhanova S.F. Productive qualities of beef cattle in the conditions of Zauralye // Vestnik of Altai State Agrarian University. - 2017. - №. 10 (156). - P. 161-167.

Alekseeva E.I., Sukhanova S.F., Leshchuk T.L. Comparative characteristics of the cow exterrier of meat direction of productivity Vestnik of Ulyanovsk State Agricultural Academy. 2017. № 4 (40). Pp. 98-102.

Altukhov A.I., Drokin V.V., Zhuravlev A.S. Food security and import substitution are the main strategic tasks of modern agrarian policy // Economy of the region. 2015. №3 (43). Pp. 256-266.

Bulatov A.P., Sukhanova S.F. Conversion of protein and fodder energy in goslings-broilers // In the collection: Actual questions of zootechnical science and practice as a basis for improving the productive qualities and health of farm animals. II International Scientific and Practical Conference. 2003. P. 21-23.

Leshchuk G.P., Alekseeva E.I., Maksunov A.V. Meat cattle breeding in Zauralye: problems and prospects / Chief herd manager. - 2012. - № 11. - P. 24-29.

Sukhanova S.F. Planning and organization of the experiment: teaching / S.F. Sukhanova, G.S. Azaubaeva, A.G. Makhalov. - Kurgan: Publishing House of the Kurgan State Agricultural Academy, 2015. - $210 p$.

Sukhanova S.F., Azaubaeva G.S., Alekseeva E.I., Lushnikov N.A. The current state of the beef cattle breeding industry in the Kurgan region, prospects, problems and ways to solve them // Chief herd manager. 2017. № 11. Pp. 53-58.

Sukhanova S.F., Azaubaeva G.S., Leshchuk T.L. The possibility of using modeling in biological research // Modern approaches to training personnel for the agro-industrial complex. Materials of the All-Russian educational-methodical conference. 2017. pp. 109-113.

Sukhanova S.F., Azaubaeva G.S., Leshchuk T.L. Use of mathematical modeling methods for processing the results of biological research // Actual problems of vocational education development. All-Russia scientific-practical conference. 2017. P. 210-214.

Sukhanova S.F., Azaubaeva G.S., Leshchuk T.L.The influence degree of the external factors on the operation of biological systems // Vestnic of Kurgan State Agricultural Academy. 2017. № 2 (22). Pp. 65-69.

Sukhanova S.F., Azaubaeva G.S., Leshchuk T.L.Koshchaev AG Biometric methods in animal husbandry. Krasnodar: KubSAU, 2017. 162p.

Sukhanova S.F., Azaubaeva G.S., Makhalov A.G. Evaluation of the influence of some factors on the indicators that ensure the functioning of the biological system of geese / / Feeding of farm animals and feed production. 2015. № 11-12. Pp. 56-62.

Sukhanova S.F., Azaubaeva G.S., Makhalov A.G. Development of a model for monitoring factors determining the effective functioning of biological systems // Chief herd manager. 2016. № 10. P. 49-54.

Sukhanova S.F, Alekseeva E.I. Forecast of the production of beef from cattle meat direction of productivity in the Kurgan region // Vestnic of the Buryat State Agricultural Academy. V.R. Filippov. 2018. № 1 (50). Pp. 130-137.

Sukhanova S.F, Alekseeva E.I. Quality of meat obtained from the animals of Hereford and AberdeenAngus breeds // Innovative and Food Safety. №4 (18). 2017. C.20-25.

Sukhanova S.F, Alekseeva E.I. Formation of the productivity of young meat breeds in the conditions of Zauralye // Vestnik APK Stavropol. № 4 (27). 2017. P.53-57.

Sukhanova S.F, Makhalov A.G. Digestibility of nutrients and energy metabolism state in goslings consuming various dosages of AVIZIM-1200 // Feeding of farm animals and feed production. 2009. № 5. pp. 23-28.

Fisinin V.I., Sukhanova S.., Makhalov A.G. Meat production and nutrient transformation in goslings consuming the enzyme preparation AVIZIM 1100 // Feeding of farm animals and fodder production. 2008. № 5. P. 40-43.

Sheveleva O.M., Bakharev A.A., Krinitsina T.P., Lysenko L.A. Meat cattle breeding of the Tyumen region // World of Innovations. 2017. №1. Pp. 112-117.

Shchukina I.V. Energy and nutritional value of meat of Aberdeen-Angus and Hereford breeds bulls // materials of Kuban State Agrarian University. 2013. №43. p. 198-199.

Submit Date: 09.01.2018, Acceptance Date: 23.02.2018, DOI NO: 10.7456/1080MSE/149

Research Article - This article was checked by Turnitin

Copyright (C) The Turkish Online Journal of Design, Art and Communication 